\section{The Relevance and Challenges of the Insurance Industry in Contemporary Administration: A Call for Researchers}

\author{
A Relevância e os Desafios da Indústria de Seguros na Administração \\ Contemporânea: Um Chamamento aos Pesquisadores
}

\author{
João Vinícius de França Carvalho*1 \\ Eduardo Flores ${ }^{1 \oplus}$ \\ Emiliano A. Valdez ${ }^{2}$
}

\section{CONTEXTUALIZATION AND A PROPOSED RESEARCH AGENDA FOR THE SECTOR}

The insurance industry is one of the most relevant segments for sustainable economic development, not only because it protects society's assets, but also because it encourages the formation of long-term provisions and reserves. Thus, it is possible to guarantee that advances in income distribution, as well as family consumption, will not regress under adverse scenarios. By promoting virtuous feedback between the productive activity and the legitimate social interest, this sector plays a central role in the promotion of collective well-being. Therefore, Actuarial Science can strongly collaborate in the development of Contemporary Administration (Bispo, 2022).

Actuarial science has risk as its primary object of study. There are risks from any source or nature. A person faces the risk of becoming ill or getting injured, limiting his/ her capacity to generate income or losing his/her properties and assets. A person faces the risk of premature death,

\footnotetext{
* Corresponding Author

1. Universidade de São Paulo, Faculdade de Economia, Administração, Contabilidade e Atuária, São Paulo, SP, Brazil.

2. University of Connecticut, Storrs, Connecticut, USA.
}

leaving behind a grieving family who may be financially dependent. Companies, in turn, deal with the possibility of losing their operational capacity because of unforeseen events. There is the additional possibility of damages caused to third parties not directly linked to the action.

Insurance contracts are financial instruments for asset protection against risks with possibly low probability of occurrence but bring severe losses, leaving those affected with damages that may lead to financial ruin. The insurance industry and risk managers interact with different fields of expertise: Finance, Economics, Accounting, Probability, Statistics, Computer Science, among others.

In Brazil, the insurance industry has been showing increasing economic importance, since there is a growing demand for protection. Between 2000 and 2018, the Brazilian insurance market experienced a real increase of $69 \%$ in premiums earned, which represents an average growth of around $3 \%$ per year, going from $1.5 \%$ to almost $4 \%$ of the GDP. 
However, the evolution of research papers is not as quick enough as this industry's development so that the Brazilian scholars have not focused their research on those who offer contracts: insurance companies. In the same period (2000-2018) the total number of active insurers (around 200, considering both insurance and reinsurance companies operating in the country) decreased by $11 \%$. After all, they offer the marketplace for managing the collective financial resources in order to provide financial protection from risks faced by the society. On the other hand, there are only few local journals that publish articles about this topic.

In this context, both insurers and researchers must handle either qualitative and quantitative models to manage risks from different sources (underwriting, operational, legal, financial and credit markets). This helps ensure that financial solvency in the long run can be maintained and an additional array of opportunities can be explored.

Without intending to conduct an exhaustive analysis, but rather seeking to stimulate debate and, above all, high quality academic research, it is possible to conjecture that there can be no socio-economic development that is consistent and inclusive without the extensive involvement of the insurance market. A recent editorial in the journal Accounting \& Finance Review of the FEA-USP Department of Accounting and Actuarial Science has drawn attention to the growth of this area in Brazil (Afonso, 2020).

More appropriately under social aegis, insurance performs distinct functions, among which we can highlight: (a) the maintenance of the individuals' assets through products, which are linked to coverage in case of damage (Euphasio Junior \& Carvalho, 2022); (b) the accumulation of savings to finance retirement and pensions, whether they are in the sphere of Social Security (Afonso \& Carvalho, 2021) or Supplementary Retirement Coverage; and (c) broad access to private hospital networks through health plans (Areias \& Carvalho, 2021). In sum, this is a sector entirely devoted to offering essential guarantees so that nations can develop in a prosperous manner.

From the perspective of business entities, the insurance market assumes a leading role in mitigating the risks that are associated with a loss of patrimony or liabilities, and thus it guarantees tranquility for corporate decision-making (Rensi \& Carvalho, 2021), creating a virtuous cycle based on gains derived from specialization in distinct economic lines of business.

It turns out that the challenges of today's insurance industry have created a need for partners who will conduct methodologically rigorous studies of relevant subjects in this sector and who are able to further the industry's progress by promoting the best possible collective well-being. Below we provide a non-exhaustive list of some of the main challenges the insurance industry faces that require greater attention from researchers. Not only are these problems interdisciplinary, but they also require a closer examination of various areas of knowledge, such as Economics, Accounting, Administration, and Statistics. Together, those different points of view that use modern tools can present robust solutions to overcome these obstacles.

\section{Alterations in the financial dynamics of retirement entities due to a reduction in the birth rate and an increase in life expectancy-the birthrate-life expectancy combination}

The dynamics of the insurance market over time requires risk managers to pay attention to the size of their monetary reserves - financial assets - that are designed to cover the outflows of cash assumed by the companies that operate them, for both life (e.g., retirement plans) and other lines of business (e.g., damage insurance).

Life and retirement insurance are much more complex because they involve extended periods. This has been combined with an intense decrease in the birth rate for a great number of nations (and Brazil is no different). On the other hand, average life expectancy has increased due to technological development and changes in people's behavior in terms of preventing diseases, which have extended the human lifespan (Cipriani \& Fioroni, 2019).

The combination of these factors makes intertemporal management truly challenging for retirement entities to the extent that this sector depends on contributions from the young to cover the payments to those who have already retired (under the pay-as-you-go regime) or on financial accumulation during the active phase for consumption when people stop working (under the fully funded regime). However, as the demographic pyramid is squeezed, the life expectancy of beneficiaries has increased, which makes it possible to state that the assets of these entities are decreasing while their liabilities are increasing, which creates a dangerous imbalance in the patrimony of these organizations.

Therefore, this subject has a prominent place in the insurance industry and related studies designed to help governments, private companies, and individuals in saving for retirement and in seeking for solutions to anticipate problems arising from the combination of decreasing birth rates and increasing life expectancy. 
Implications of a lower prime interest rate on the growth of financial reserves for retirement entities

Due to regulatory concerns, a large portion of financial applications realized by the insurance market is concentrated in federal government bonds. This applies not only to Brazil (Brazil Central Bank Resolution $4,444 / 2015$ is the legislation, which determines admissible guarantee assets) but to other jurisdictions as well, since government bonds are very liquid and very safe securities. Thus, in theory they do not present the risk of not offering nominal remuneration.

The returns on government bonds are linked to the prime interest rate in each country. In some countries, these rates have decreased to the extent that when we discount for inflation, the returns on these bonds have become close to null or even negative at times. Thus, the real interest rates for government bonds are not enough to recover the capital invested in them minus inflation.

This is the reason why these low interest rates and the imposition of investing almost solely in government bonds have limited these entities to investing in low return securities, which have inadequate returns for the risks that they assume. As a consequence, the advantage of investing this capital over the long term is not compatible with the remuneration necessary to maintain the financial solvency of these organizations.

On the other hand, there is evidence that high interest rates inhibit the development of certain insurance segments (Flores, Carvalho, \& Sampaio, 2021), by making these financial revenues more advantageous than the buying of the insurance itself. This can further inhibit the formation of a competitive insurance market focused on the offering of products that meet the needs of their consumers.

Therefore, it is fundamental and necessary to conduct studies that will attract the attention of regulatory agents to the fact that insurance agents need greater managerial leeway in terms of their investment portfolios. This is yet another contribution that academic studies of high methodological quality can offer: the guaranteed investments of insurers should not be sought from investing solely in federal government bonds, but rather in the accumulation of financial resources that meet the demands of various stakeholders, including active participants, beneficiaries, shareholders, and, last but not least, the society at large.
The insurance market sandbox and the need to develop new products

Innovation in the insurance market is the order of the day. Ranging from improving existing products to the formulation of new instruments of protection, the insurance market has been undergoing a profound transformation, which has been most influenced by the countless possibilities offered by recent data collection, processing, and analysis technologies.

The advent of 'big data' has made it possible to expand insurer databases, allowing to analyze factors and variables that previously could not be examined by traditional statistical and actuarial models. With the development of deep learning through the usage of sophisticated machine learning, it is possible to develop faster actuarial pricing and portfolio monitoring (Quan $\&$ Valdez, 2018). This helps improve the array of products on offer by customizing them to the idiosyncratic profile of each policyholder.

Equally relevant in terms of the evolving changes in the industry is a reduction in government participation in providing certain types of retirement coverage. Increasing private initiative participation in the offering of products that mitigate the risk of reduced social well-being can accelerate the development of new products. Cybernetic (Xu \& Hua, 2019), parametric (Lin \& Kwon, 2020), and microinsurance policies (Cole, 2015), among other varieties for vulnerable populations, are part of the global agenda, which sees a future characterized by a more protected world.

Finally, but of no less relevance, the challenges of climate change have presented the insurance market with a great opportunity to offer financial solutions to help society face the risks of a new world crisis (Broberg, 2020). Alternatives such as flood insurance can protect entire families from natural disasters, which generally tend to affect those who are most socially vulnerable (Mendes-da-Silva, Lucas, \& Carvalho, 2021).

\section{SUMMARY OF WORKS THAT THE READER WILL ENCOUNTER IN THIS SPECIAL ISSUE ABOUT THE INSURANCE INDUSTRY}

Before our brief comments about the studies that comprise this special Call for Papers, we would like to thank the editors-in-chief of the Journal of Contemporary Administration, namely Professor Wesley Mendes-daSilva (the former editor-in-chief) and Professor Marcelo de Souza Bispo (the current editor-in-chief) for the invitation they extended in 2020 to produce this special 
issue featuring the insurance industry. We wish to express our gratitude for this opportunity.

Researchers from various institutions concerned with a variety of areas have answered our call by offering studies that have a real impact on society. We wish to thank all of them for sending in their studies, including the ones that unfortunately were not accepted. The review process prior to approval involved intense communication among the authors, invited editors, and anonymous reviewers. Our thanks to all for not giving up in their efforts and for bringing this edition to fruition.

Thus, we would like to extend our warm wishes to the anonymous reviewers who performed their valuable work with consummate professionalism and demonstrated their commitment to academic production of the highest quality and rigor. Without the generous donation of the reviewers' time through multiple rounds of evaluation, none of this would have been possible.

It is with great pride that we present the works below, which make up this special edition.

\section{An application of geographically weighted quantile lasso to weather index insurance design}

This article by Daniel Lima Miquelluti, Vitor Augusto Ozaki, and David José Miquelluti from USP demonstrates that a geographically weighted quantile lasso is an alternative way to face the risks found in Brazil's agricultural insurance market. The findings indicate that this lasso can surpass the protective benefits offered by traditional agricultural production insurance.

This work is of singular relevance to the Brazilian actuarial market, because it takes into account weather risk, market innovations, and the expected options available to market agents in the formulation of new insurance arrangements.

\section{MAC: A proposal for consistent actuarial interest rates in pension funds}

This study conducted by Sandro de Azambuja and Carlos Heitor Campani offers a new proposal for the formation of consistent actuarial goals (MAC) with the returns offered by retirement plans. The study's conclusions demonstrate that the Brazilian National Superintendency of Supplementary Retirement Benefits (Previc) can improve the normative ecosystem of closed retirement entities through the adoption of the MAC.
This is an essential article for the private retirement industry in Brazil, because it captures the complexity that supplementary retirement entities have encountered recently in their quest to achieve the actuarial goals of pension plans in the face of restricted options in choosing their investment portfolios. However, rather than presenting the problem, this article offers an alternative solution.

\section{Uncertainty of claims provisions from the analysis of financial statements}

This article by Roberto Bomgiovani Cazzari and Guilherme Rodovalho Fernandes Moreira analyzes whether the technical claims provisions of Brazilian private insurance companies are sufficient. Based on the public financial statements of insurers, the authors identify a lack of standardization in the divulging of public information and indicate what can happen when a company tries to manage its results.

This study sheds light on accounting numbers examined from the point of view of actuarial criteria and parameters, which can destabilize the interests of various agents interested in the continuity of the insurance company over the long term. While insufficient technical provisions place the solvency of these entities at risk, an overestimate of the necessary provisions can depress accounting profits, which mainly affect shareholder dividends.

\section{Surety bonds for Brazilian infrastructure examined from the point of view of transaction costs and agency theory}

This work by Tulio Henrique Moreira Marques, Mario Henrique Ogasavara, and Frederico Araujo Turolla presents an analysis of insurance for infrastructure projects in Brazil. The authors, based on a study of primary data collected through interviews, demonstrate that agency conflicts and elevated transaction costs can harm this market's development.

This study's relevance resides in its demonstration of several aspects that impede the advance of insurance. This article also shows a strong alignment with insurance theory, which preaches the general idea that under conditions of moral risk and adverse selection, there is no stimulus to strengthen certain insurance lines of business. 


\section{Earnings persistence and stock market reaction to earnings in the international insurance industry}

This study conducted by Renê Coppe Pimentel analyzes the persistence of profits in a comparison of insurers across various nations. The findings indicate that the cash flow of research entities is considerably more stable than accounting results and the reason for this discrepancy is due to the elements linked to the competence regimes contained within the profits/losses.

\section{REFERENCES}

Afonso, L. E. (2020). The actuarial science editorship of the Accounting \& Finance Review: Some general considerations. Revista Contabilidade \& Finanças, 31(82), 9-13. https://doi.org/10.1590/1808-057×202090320

Afonso, L. E., \& Carvalho, J. V. F. (2021). Show do trilhão no RGPS? Quantificando os aspectos fiscais e distributivos da reforma da previdência do governo Bolsonaro. Revista Brasileira de Economia, 75(2), 1-20. Retrieved from https://bibliotecadigital.fgv.br/ojs/index.php/rbe/article/ view/80203

Areias, C. A. C., \& Carvalho, J. V. F. (2021). Reinsurance in the supplementary health: A counterfactual study on the impacts of reinsurance treaties adoption by healthcare plans operators in Brazil. Brazilian Business Review, 18(2), 217-235. https://doi.org/10.15728/bbr.2021.18.2.6

Bispo, M. S. (2022). Reflecting on contemporary administration. Revista de Administração Contemporânea, 26(1), e210203. https://doi.org/10.1590/1982-7849rac2022210203.en
Despite the importance of the results brought by the researcher for what is conventionally termed 'positive accounting theory,' the findings indicate that the accounting treatment applied to insurers has produced, at least to a certain extent, a displacement of the flow of profits in these entities. This conjecture can be seen as an example of the importance of rethinking insurance accounting in light of the data quality of insurers, especially when they are on the brink of implementing an international norm for entities that issue insurance contracts: the IFRS 17. everyone!

We hope this will be a great inspiring reading for

Broberg, M. (2020). Parametric loss and damage insurance schemes as a means to enhance climate change resilience in developing countries. Climate Policy, 20(6), 693-703. https://doi.org/10.1080/14693062.2019.1641461

Cipriani, G. P., \& Fioroni, T. (2019). Endogenous demographic change, retirement, and social security. Macroeconomic Dynamics, 25(3), 609-631. https://doi.org/10.1017/S1365100519000269

Cole, S. (2015). Overcoming barriers to microinsurance adoption: Evidence from the field. The Geneva Papers on Risk and Insurance - Issues and Practice, 40(4), 720-740. https://doi.org/10.1057/gpp.2015.12

Euphasio Junior, J. W., \& Carvalho, J. V. F. (2022). Reinsurance and solvency capital: Mitigating insurance companies' ruin probability. Revista de Administração Contemporânea, 26(1), e200191. https://doi.org/10.1590/1982-7849rac2022200191.en 
Flores, E., Carvalho, J. V. F., \& Sampaio, J. O. (2021). Impact of interest rates on the life insurance market development: Cross-country evidence. Research in International Business and Finance, 58, 101444. https://doi.org/10.1016/j.ribaf.2021.101444

Lin, X., \& Kwon, W. J. (2020). Application of parametric insurance in principle-compliant and innovative ways. Risk Management and Insurance Review, 23(2), 121-150. https://doi.org/10.1111/rmir.12146

Mendes-da-Silva, W., Lucas, E. C., \& Carvalho, J. V. F. (2021). Flood insurance: The propensity and attitudes of informed people with disabilities towards risk. Journal of Environmental Management, 294, 113032. https://doi.org/10.1016/j.jenvman.2021.113032

\section{Authorship}

\section{João Vinícius de França Carvalho*}

Universidade de São Paulo, Faculdade de Economia, Administração, Contabilidade e Atuária

Av. Luciano Gualberto, no 908, Butantá, 05508-010, São Paulo, SP, Brazil.

E-mail: jvfcarvalho@usp.br

(D) https://orcid.org/0000-0002-1076-662X

\section{Eduardo Flores}

Universidade de São Paulo, Faculdade de Economia, Administração, Contabilidade e Atuária

Av. Luciano Gualberto, no 908, Butantã, 05508-010, São Paulo, SP, Brazil.

E-mail: eduardoflores@usp.br

(D) https://orcid.org/0000-0002-5284-5107

\section{Emiliano A. Valdez}

University of Connecticut

341 Mansfield Road U1009, 06269-1009, Storrs, Connecticut, USA.

E-mail: emiliano.valdez@uconn.edu

(D) https://orcid.org/0000-0003-4037-8385

* Corresponding Author

\section{Conflict of Interest}

The authors have stated that there is no conflict of interest.

\section{Copyrights}

RAC owns the copyright to this content.

\section{Plagiarism Check}

The RAC maintains the practice of submitting all documents approved for publication to the plagiarism check, using specific tools, e.g.: iThenticate..
Quan, Z., \& Valdez, E. A. (2018). Predictive analytics of insurance claims using multivariate decision trees. Dependence Modeling, 6(1), 377-407. https://doi.org/10.1515/demo-2018-0022

Rensi, R. T., \& Carvalho, J. V. F. (2021). Operation car wash: Impacts on the executives' liability insurance market. Revista de Administração Contemporânea, 25(2), e190386. https://doi.org/10.1590/1982-7849rac2021190386.en

Xu, M., \& Hua, L. (2019). Cybersecurity insurance: Modeling and pricing. North American Actuarial Journal, 23(2), 220 249. https://doi.org/10.1080/10920277.2019.1566076

\section{SCIENTIFIC EDITORIAL BOARD AND EDITORIAL TEAM FOR THIS ISSUE:}

\section{Editorial Council}

Anielson Barbosa da Silva (UFPB, João Pessoa, PB, Brazil) Antonio Carlos Gastaud Maçada (UFRGS, Porto Alegre, RS, Brazil) Ely Laureano Paiva (FGV, São Paulo, SP, Brazil)

Rogério Hermida Quintella (NPGA/UFBA, Salvador, BA, Brazil) Valmir Emil Hoffmann (UnB, Brasília, DF, Brazil)

\section{Editor-in-chief}

Marcelo de Souza Bispo (UFPB, João Pessoa, PB, Brazil)

\section{Associate Editors}

Ariston Azevedo (UFRGS, Porto Alegre, RS, Brazil)

Carolina Andion (UDESC, Florianópolis, SC, Brazil)

Denize Grzybovski (UPF, Passo Fundo, RS, Brazil)

Eduardo da Silva Flores (FEA/USP, São Paulo, SP, Brazil)

Elisa Yoshie Ichikawa (UEM, Maringá, PR, Brazil)

Emílio José M. Arruda Filho (UNAMA, Belém, PA, Brazil)

Evelyn Lanka (Cranfield School of Management, Bedford, United Kingdom)

Fernando Luiz Emerenciano Viana (Unifor, Fortaleza, CE, Brazil) Gaylord George Candler (University of North Florida, Jacksonville, Florida, USA)

Gustavo da Silva Motta (UFF, Niterói, RJ, Brazil)

Keysa Manuela Cunha de Mascena (Unifor, Fortaleza, CE, Brazil) Ludmila de Vasconcelos Machado Guimarães (CEFET-MG, Belo Horizonte, MG, Brazil)

Natália Rese (UFPR, Curitiba, PR, Brazil)

Orleans Silva Martins (UFPB, João Pessoa, PB, Brazil)

Pablo Isla Madariaga (Universidad Técnica Federico Santa María, Chile)

Paula Castro Pires de Souza Chimenti (UFRJ/Coppead, Rio de Janeiro, Brazil)

Rafael Chiuzi (University of Toronto Mississauga, Mississauga, ON, Canada)

Sidnei Vieira Marinho (Univali, São José, SC, Brazil) 


\section{Scientific Editorial Board}

André Luiz Maranhão de Souza-Leão (UFPE, Recife, CE, Brazil)

Aureliano Angel Bressan (CEPEAD/UFMG, Belo Horizonte, MG, Brazil)

Bryan Husted (York University, Canada)

Carlos M. Rodriguez (Delaware State University, USA)

Cristiana Cerqueira Leal (Universidade do Minho, Portugal)

Diógenes de Souza Bido (Mackenzie, São Paulo, SP, Brazil)

Erica Piros Kovacs (Kelley School of Business/Indiana University, USA)

Elin Merethe Oftedal (University of Stavanger, Norway)

Fábio Frezatti (FEA/USP, São Paulo, SP, Brazil)

Felipe Monteiro (INSEAD Business School, USA)

Howard J. Rush (University of Brighton, United Kingdom)

James Robert Moon Junior (Georgia Institute of Technology, USA)

John L. Campbell (University of Georgia, USA)

José Antônio Puppim de Oliveira (United Nations University, Yokohama, Japan)

Julián Cárdenas (Freie Universität, Berlin, Germany)

Lucas A. B. de Campos Barros (FEA/USP, São Paulo, SP, Brazil)

Luciano Rossoni (UniGranRio, Rio de Janeiro, RJ, Brazil)

M. Philippe Protin (Université Grenoble Alpes, France)

Paulo Estevão Cruvinel (Embrapa Instrumentação, São Carlos, SP, Brazil)
Rodrigo Bandeira de Mello (Merrimack College, USA)

Rodrigo Verdi (MIT Massachusetts Institute of Technology, Cambridge, USA)

Valter Afonso Vieira (UEM, Maringá, PR, Brazil)

Wagner A. Kamakura (Jones Graduate School of Business, Rice University, Houston, USA)

\section{Editing}

Typesetting and normalization to APA standards: Kler Godoy (ANPAD, Maringá, Brazil); Simone L. L. Rafael (ANPAD, Maringá, Brazil).

Frequency: Continuous publication.

Circulation: Free open access to the full text.

\section{Indexing, Directories and Rankings}

Scielo, Redalyc, DOAI, Latindex, Cengage/GALE, Econpapers, IDEAS, EBSCO, Proquest, SPELL, Cabell's, Ulrichs, CLASE, Index Copernicus International, Sherpa Romeo, Carhus Plust, Academic Journal Guide (ABS), DIADORIM, REDIB, Sumários.org, ERIHPlus, EZB, OasisBR, IBZ Online, WorldWideScience, Google Scholar, Citefactor.org, MIAR, Capes/Qualis. 